\title{
Recent Improvements of the PV Solar Energy Generation Performance
}

\author{
Temesgen Abera Takiso, Birtukan Tekle Manbecho
}

\begin{abstract}
PV solar energy is the upcoming king of the energy source in the world, which is the fastest growing, most available, sustainable, clean, and environmentally friendly renewable energy. The essential characteristic of PV solar energy is generating the maximum power at mid-day. At the same time, the energy demand is high during the daytime. Due to this, PV solar energy replaces the conventional energy demand at peak periods. The sun is the source of PV solar energy, and it changed into electricity directly by using solar cells, which are made from semiconductor materials called silicon. Therefore, PV solar energy plays a crucial role in providing usable energy, and as well as reducing carbon dioxide emissions. However, the solar energy generation systems not achieved the desired efficiency yet, because of many unsolved problems like weather conditions, losses, materials made by and so on. The aims of this paper is to review the current literature on the improvement of the PV solar energy generation system's overall performance. First, to figure out the existing challenges, like environmental factors and natural phenomena that affect the PV solar modules efficiency. Then it presents the techniques that are used to enhance the PV solar modules overall performance. Finally, to propose the best ways and techniques to improve the PV modules efficiency and suggest to further studies
\end{abstract}

Key words: PV solar module; Power output; Energy efficiency improvement

\section{INTRODUCTION} rapidly due to the increased population number and technologies. Furthermore, it perform a crucial role in the country's economic development. Therefore, fulfilling the world's energy demands is a fundamental and urgent issue $[1,2]$. Depending on the conventional methods to generate energy caused environmental problems like global warming; however, without energy world is nothing. Moreover, Conventional energy sources may not fill the future demands of the energy in the world because it is limited and non-renewable [2]. Therefore, the energy sectors have to look for non-conventional energy sources such as solar energy, hydropower energy, wind energy, etc. [2, 3].

Manuscript received on September 09, 2021.

Revised Manuscript received on September 14, 2021.

Manuscript published on September 30, 2021.

* Correspondence Author

Temesgen Abera Takiso*, Ph.D Degree Student at College of Mechanical and Vehicle Engineering, Hunan University, China. Email: temeabera17@hnu.edu.cn

Birtukan Tekle Manbecho, worked at Infrastructure of the Municipality of Gimbichu city, Ethiopia. Email: buretekle@yahoo.com

(C) The Authors. Published by Blue Eyes Intelligence Engineering and Sciences Publication (BEIESP). This is an open access article under the CC BY-NC-ND license (http://creativecommons.org/licenses/by-nc-nd/4.0/)
Currently, the need for energy worldwide increases

International Energy Agency (IEA) [4] states that Renewable Energy development has a remarkable role in reducing carbon dioxide emissions and providing alternative energy sources rather than depending on only fossil fuels. Scaling up usable energy or electricity from renewable resources is significant for decarbonizing the globe's energy system [5]. As a result, the global carbon dioxide emissions from power sectors will fall by 38\% from 2020 to 2030 [4].

Solar energy $[2,6]$ is clean, sustainable, highly available and environmentally friendly renewable energy source. The mean solar radiation that reaches the surface of the our plant's is 8000 times greater than the mean power utilization at the global level [7]. There are numerous methods of exploiting solar energy, but the authors focused only on PV solar energy in this review. The PV solar energy $[8,9]$ directly changes solar radiation into useable electricity by using solar cells made up of semiconducting materials called silicon. The use of PV solar energy increases as well as the manufacturing industry increases, and the price of PV solar modules decreasing from time to time [3-5]. PV solar power is one of the most mature, costcompetitive, and fastest-growing non-conventional energy technologies [5]. It is a reliable, long-lasting, and maintenance-free source of energy [7, 10]. The essential characteristic of PV solar energy is generating the maximum energy during mid-day, which means the electricity demand is higher at this time, So it can simply replace natural gas at a time of maximum demand [11]. PV solar power is the upcoming new king of energy sources in the world, which grows by an average of $13 \%$ per annum from 2020 to 2030 [4, 12, 13]. The annual energy outlook 2020 (AEO, 2020) [11] said that the power production from non-conventional energy sources would upturn from $18 \%$ of overall production in 2018 to 38\% by 2050. But the only solar energy provides the maximum to the development of non-conventional energy generation, which increases from $13 \%$ of total energy generation in 2018 to $46 \%$ by 2050 . Based on the connection with the power grid or not, PV solar energy is classifieds into grid-tied or standalone types [14]. Typical PV solar energy systems have solar cells, solar modules, charge controllers, inverters, and storing batteries [5]. Each component of the system directly correlates with the PV solar energy generating efficiency [12]. The PV solar power output and its efficiency depend on environmental weather conditions like solar radiation, wind speed, snowfall, ambient temperature, and PV module orientation [3, 13, 15-17]. From the articles [5, 18-21] There are various types of PV solar cell technologies like Monocrystalline silicon solar cell, Polycrystalline silicon solar cell,

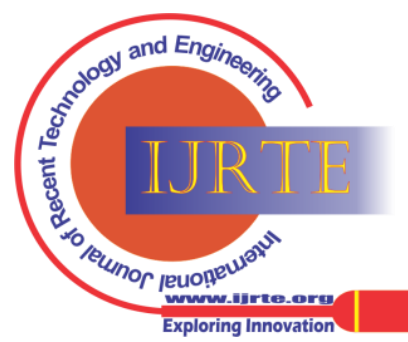




\section{Recent Improvements of the PV Solar Energy Generation Performance}

Thick-film silicon solar cell, amorphous silicon solar cell, and other thin-film solar cell. The monocrystalline and polycrystalline PV cells are the first generation PV solar panels, and they are designed using microelectronic manufacturing techniques. While the thin-film PV solar cells are referred to as the second generation of PV panels, they are designed by using amorphous silicon (A-Si), copper-indium-gallium-diselenide (CIGS), and cadmium telluride (CdTe), semiconductor materials. In the current global PV solar market, the first generation silicon-related PV solar panels hold nearly $95 \%$ of the worldwide market, since the efficiency of monocrystalline and polycrystalline PV modules are approximately $21.7 \%$ and $17.8 \%$, respectively; in comparison, the thin-film PV solar modules share only $5 \%$ of the global market since efficiencies are ranging between $15 \%$ to $16 \%$.

The sun is used as a PV solar energy source. Sunlight is also the main and significant factor for PV solar modules to generate electricity. Even though heat energy affects the solar module's performance, increasing the temperature made overheating the PV module and its effects reduces the PV solar power output and efficiency [8]. The PV module of silicon cell temperature rise by $1^{0} \mathrm{C}$ reduces the efficiency by $0.4 \%-0.5 \%$. In addition to minimizing the power output, it also affects the PV solar modules lifespan [6, 16, 22]. IRENA2019 [5] reported that the chemical reactions on the PV solar modules are double for every $10^{\circ} \mathrm{C}$ if the temperature increased above the room temperature $\left(25^{\circ} \mathrm{C}\right)$, which caused deteriorate of the PV modules. To improve the PV solar power output, we need to remove or minimize the heat from the modules as much as possible. The materials in the back of PV solar modules are not good enough and are weak to remove the heat energy, which caused a decrease in the system's efficiency [8].

Further, the PV solar cells' quality is directly related to the PV solar system's efficiency and power output. If the efficiency is low, the desired PV solar module must be high to fit the wanted power output; this made the PV solar module cost high and need a prominent place to install. Therefore, many investigations and developments were conducted on PV solar energy generation, applications, and performance, even though the area still needs further research and continuous improvements [23-26]. This article aims to review recent literature on the improvement of the power output and performance of the generating PV solar energy, to analyze different techniques applied to enhance PV solar energy efficiency and research and development ( $\mathrm{R}$ and D) information. Moreover, to suggest for further investigation and research.

The layout of the article is presented as, Section I introduction, Section II reviewed the literature on the current status of improving the performance and power output and factors that affect the PV solar energy generation efficiency. Then, put forward the suggestions and recommendations for further research progress in section III. Finally, section IV is the conclusion of the paper.

\section{CURRENT STATUS OF PV SOLAR ENERGY PERFORMANCE AND POWER OUTPUT}

This section is designed to review current scientific papers on improving PV solar module power output and efficiency. Furthermore, the challenges and factors that caused the decrease in the PV solar module's overall performance.

\section{A. Factors affecting efficiency and power output}

In the non-conventional energy sector, especially PV solar energy generation systems, the main challenges are achieving the desired power output and efficiency; it needs much focus, research, and improvement. Besides, based on different researchers' and manufacturers' perspectives and experimental results, various factors that influence the general performance of PV solar modules have filtered out [27-34]. Therefore, this section presents some factors that negatively influences the PV solar energy generation system's efficiency.

\section{a. Environmental factors and weather conditions}

The PV solar energy generation systems are affected by environmental and weather conditions. The environmental factors like shading, dust, humidity, and so on tend to block sunlight from reaching the PV arrays then they limited the capacity of the generating power of solar module, and they reduce the overall efficiency by $30 \%$ to $40 \%$, especially in desert areas [35, 36]. Therefore, the PV solar modules performance is hurted by environmental factors, and such factors are described in the Fig.1 below.

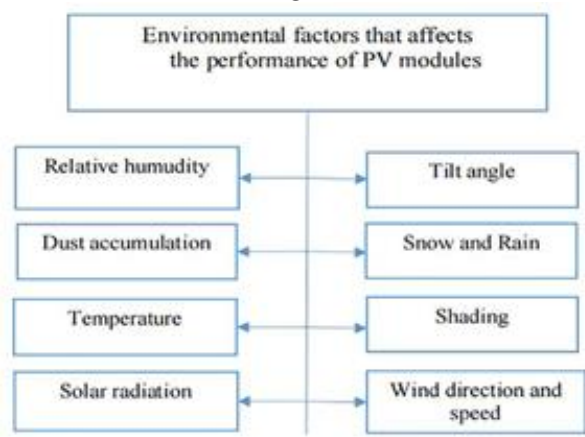

Figure 1 environmental factors that influence the PV solar energy performance.

\section{Temperature}

In generating the PV solar energy, the temperature is a critical parameter that hurting the PV solar module's efficiency [37, 38]. The temperature is inversely correlated to the PV solar module efficiency; when the temperature rises, the PV solar energy generating systems performance is reduced [39]. The experimental research was conducted with different seasons to analyze the temperature effects on the solar modules; the study results attested that the PV module the temperature raised to $53.5^{\circ} \mathrm{C}$, which rises the power loss until $12.63 \mathrm{~W} / \mathrm{m}^{2}$. Therefore, the study concluded that overheating of PV solar modules is highly hurted the PV solar energy systems performance, and less ambient temperature and high solar radiation are ideal components for the PV solar energy generation systems [10, 40].

\section{Dust accumulation}

In [20] paper, the authors demonstrated that two polycrystalline PV modules, the first module is considered as reference module, it does not allow to store dust.

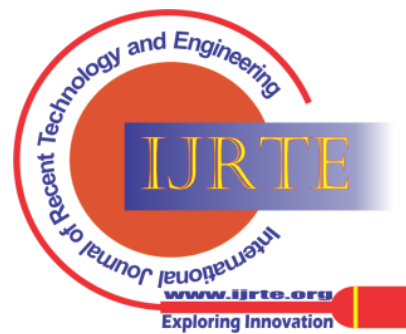


It is cleaned before starting to record the readings. In contrast, the second module is considered an experiment conducted module; it is allowed to accumulate dust and not cleaned during the demonstration. The first and second modules' produced power is $136.1 \mathrm{~W}$ and $119.12 \mathrm{~W}$, respectively, within the same period. The efficiency of the first module and the second module is $13.86 \%$ and $11.7 \%$, respectively. The result from the experiment attested that dust accumulation decreases the energy output and efficiency by $8.8 \%$ and $11.86 \%$, respectively, because the dust spread over the solar radiation and reduced PV modules' quality. And the dust accumulation affecting the PV panels performance depends on the regional conditions, which means that the quantity of dust is contained by those regions' weather [41].

The experiment is conducted on two rooftop PV solar modules for four months (October, December, June, and March) to investigate the consequences of dust accumulation, one module is cleaned regularly, and the other is not cleaned. It was allowed to accumulate dust naturally. The study verified that the dust accumulations is seriously hurt the PV solar module performance. Dust particles covered the PV module slightly, it affects the current but the voltage is continuous the same. Nevertheless, the dust particles covered PV modules highly or whole shaded, the overall system may affected or no power is produced [10]. Furthermore, as you can see in the Fig.2 below the comparison between the cleaned PV solar module and uncleaned PV solar module, the maximum power output generated by the cleaned module is 296 Watt, whereas by the uncleaned module is 170 Watt within one day from morning to evening [42].

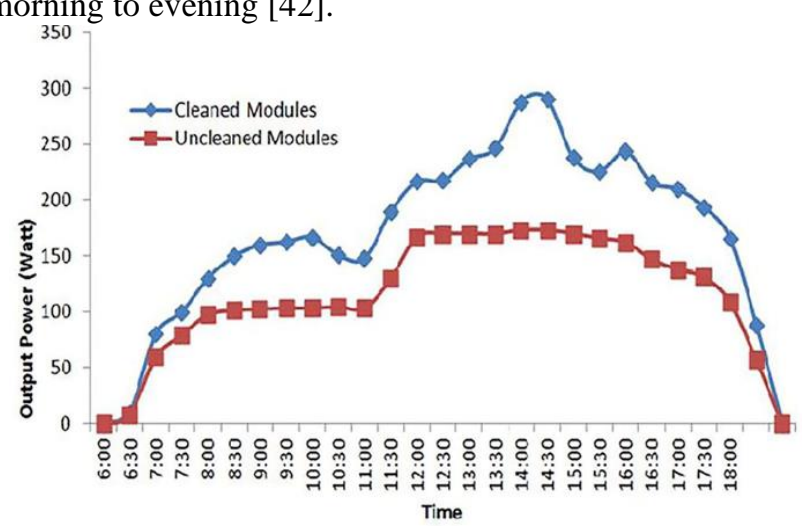

Figure 2 dust accumulation consequences on the PV module [42].

The experimental study [17] investigated the dust accumulation impacts on PV solar modules with varying dust layers such as a thick layer, medium layer, and without any dust on it at a different time in a day. The study notified that power generation efficiency decreased by dust accumulations on the PV solar module. The dust accumulation decreases by $2.73 \%$ to $4.4 \%$ on average energy per day [36]. The power output is inversely correlated to the dust layer. The authors of [17] paper also concluded that heat effects on the PV solar generation are not very high, whereas accumulation of dust affects the PV module primarily. The moisture and heat have fewer effects on PV solar generation, and it may crack the upper glass of the PV module.
Moreover, the authors demonstrated that the dust accumulation impacts on the PV solar module surface; however, the raised idea about heat effects on PV modules is limited. Because the problem of the PV solar module power output and efficiency is coming from overheating the PV modules. Many manufacturers and researchers investigated different ideas about the effects of heat/temperature on PV module, PV module turns only $15 \%$ to $20 \%$ of incoming energy from the solar light into electricity, and however, the remaining part of the energy is transformed into heat $[5,16$, 40]. Therefore, the temperature effects on the PV solar module performance is very big, can decreases the power output by $10 \%$ to $25 \%$ [40]. The dust accumulation density is reduces when the wind speed/ air inlet speed increases and the PV solar module tilt angle decreases [43].

\section{Shading effects}

Shading harms the overall efficiency of PV solar modules, as it changes the flow of electricity through the modules [44]. Therefore, it is considered one of the chief sources of loss in PV solar systems [32]. The experimental study [20] investigated the partial shading effects of the PV solar module on the short circuit current, open-circuit voltage, and power output. From the experiment, the PV solar modules' three-quarters, half, and quarter shading, both short circuit current and open-circuit voltage are decreased. The power output reduction for the three-quarters, half, and quarter shading is $92.6 \%, 45.1 \%$, and $33.7 \%$, respectively. Therefore, when the shading area of the PV solar module increases, the loss of energy output increases, and the PV solar energy system's overall performance is decreased. Therefore, to get the maximum and sufficient energy from PV solar cells, selecting the proper installation location is crucial.

In the article[10], the research on shading effects of the PV solar module using Matlab software, the simulation set up consists of 20 sets of PV modules linked in seriesparallel combination. Three shading levels, such as 8 modules shading in a series pattern, 12 modules shading in a series pattern, and 8 modules uneven shading in a matrix, are demonstrated by the Simulink model. Further, the Simulink conditions are utilized with four different irradiance levels such as $800 \mathrm{~W} / \mathrm{m}^{2}, 600 \mathrm{~W} / \mathrm{m}^{2}, 400 \mathrm{~W} / \mathrm{m}^{2}$, and $200 \mathrm{~W} / \mathrm{m}^{2}$. The experimental results proved that the PV solar power output decreased when the level of shading or the number of shaded modules increased. And for unevenly shaded PV modules, there are different peak PowerPoints, which is challenging to choose the optimal operating point. In the literature [44], the analysis was conducted on partial shading consequences on different module configurations of series, serious- parallel, total cross-tied, bridge link, and honeycomb; the results verified that the total cross-tied configuration had maximum efficiency in terms of shading losses, mismatch losses, fill factor and maximum power compared under all shading conditions.

\section{Bird droppings}

The bird droppings are the feces of birds, contain liquid and semi-solid particles.

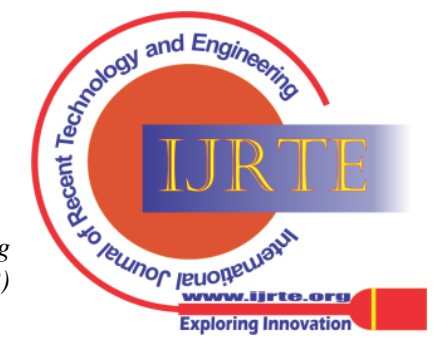




\section{Recent Improvements of the PV Solar Energy Generation Performance}

Bird droppings factors reduce the PV solar energy generation performance since their effects reduce the light transmittance [45]. Bird droppings are considered as form of shading that prevents solar radiation from reaching the solar module's surface. The experimental study investigated that the energy output reduced by $7.4 \%$ when the bird droppings accumulated on the PV solar module [20]. According to the article [46], the bird droppings effect level is different due to the plate inclination. The demonstrated tilt angles were $(\beta<$ $\left.25^{\circ}\right),\left(25^{\circ} \leq \beta \leq 60^{\circ}\right)$, and $\left(60^{\circ} \leq \beta \leq 90^{\circ}\right)$; results validated that the optimal inclination is $\beta\left(40^{\circ}\right)$ in between $\left(25^{\circ} \leq \beta \leq\right.$ $60^{\circ}$ ) has fewer droppings effect relatively. The PV solar module efficiency decreasing rate rely on the bird dropping accumulation capacity. The experimental results attest that the bird dropping effects reduce the short-circuit current by $35 \%$ since bird droppings accumulated on the low iron glass and by $46 \%$ since bird droppings accumulated on the acrylic plastic [45].

\section{Effect of Humidity}

Humidity is a non-uniform moisture concentration, which affects the PV solar energy efficiency and power output. In addition, the deposition of humidity also reduced the life span of modules because it caused corrosion on the PV solar modules surface [39]. Based on the Fig.3, the power output is inversely proportional to the humidity. According to the article [47], the tested results verified that the humidity influences the PV solar modules efficiency; since humidity increases, the heat exchange rate decreased.

\section{Powers (Watts) Vs Humidity(\%)}

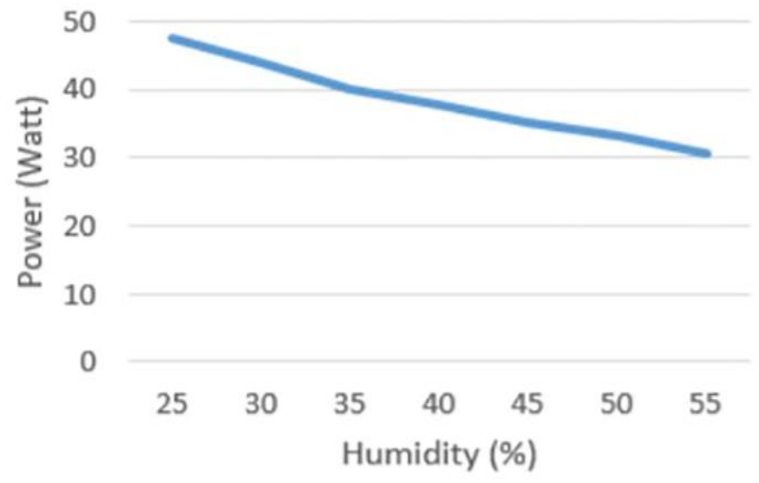

Figure 3 humidity VS power out of PV module [39]. b. Losses

The solar energy generation system has different components; as mentioned in the introduction section, they all directly correlate with the PV solar module's overall performance. Besides, each component has power losses, but the amount of the loss depends on their quality. The PV module losses due to the system's components are the inverter losses, cables losses, array mismatch losses, thermal losses, reflection losses, module quality losses, and so on [48-50]. The losses caused by these components influence the PV solar module efficiency and power output. In the PV solar energy generation process, only $15 \%-20 \%$ of incoming sun energy is used by the PV module, whereas the rest of the energy is transformed in the form of heat, which is called thermal losses [5, 16, 51, 52]. When the PV solar module temperature increases, the power loss is also increased [40]. The thermal losses vary based on environmental conditions. There are energy losses on the PV solar systems caused by energy conversion during the process, even without considering external factors like dust, snow, and others. The error between the net generated power and the estimated amount of power generated by the PV solar panels manufacturers are known as power losses[20]. The losses due to incompatible interconnection of the modules or solar cells negatively impact the power output [53].

\section{B. Ways or techniques to improve efficiency and power output}

PV solar industry is changed and improved with high speed from time to time. Now a day, pursuing high power output and efficiency is researchers, manufacturers, and innovators prime objectives [54-57]. This section presents different methods used to enhance the PV solar panels efficiency investigated by various authors and researchers currently.

\section{a. Cooling techniques}

The temperature level of the PV solar module surface must be uniform and suitable unless the solar energy generation systems cannot give the desired results. Consequently, the cooling techniques are one of the best solutions to remove or reduce heat from the PV module's surface [58-60]. In literature [16, 22, 41, 61], there are two major cooling techniques. Two of them are used to reduce the operating temperature and then enhance the PV solar module's performance. First, passive cooling techniques: it works naturally and not required energy to remove heat from the solar panels. Passive cooling techniques such as heat pipe cooling, natural air cooling, water cooling, and phase change materials (PCM) cooling are easy to operate and economical. Second, active cooling techniques: required energy to remove heat from the solar panels. Examples of Active cooling methods are forced air cooling, refrigerant-based cooling, and forced water cooling. Active cooling techniques gave better cooling performance than passive cooling techniques [62]. The detail of the primary cooling techniques are classified in the Fig.4.

\section{Air cooling techniques}

Natural Air cooling is the standard technique for PV modules because of its simple, has no extra energy required, and is cost-effective. The flowing of natural air over PV modules reduces temperature by convection. Leaving an air gap to circulate air between the PV panels and building is the most efficient cooling technique for PV solar energy generating systems mounted on the rooftop. Thereby, it can reduce the PV solar Module mean temperature from $77^{\circ} \mathrm{C}$ to $39^{\circ} \mathrm{c}$ [22, 63]. Forced air cooling is an active technique, which uses a fan to chilling PV modules. Forced air cooling techniques are open channel beneath, an array of air ducts, etc. In [64], the experimental study was carried out to examine the impacts of the forced air cooling method on the PV solar module, and the results verified that the achieved efficiency was $19.31 \%$ at an airspeed of $2.4 \mathrm{~m} / \mathrm{s}$.

\section{Water cooling techniques}

Water-based cooling techniques for PV module has been started since the end of 1960 [58]. 
Nowadays, this cooling technique has a lot of investigation and improvement, and it enhanced the performance of solar power generation systems. Water cooling techniques are natural water-cooling, Water spraying, forced water circulation, and Nanofluids based cooling technique.

\section{Natural water cooling technique}

The natural water-cooling technique is simple and has no complexity to apply. The falling of natural water on the PV module surface reduced the temperature from the PV solar module, which improved the PV solar modules'

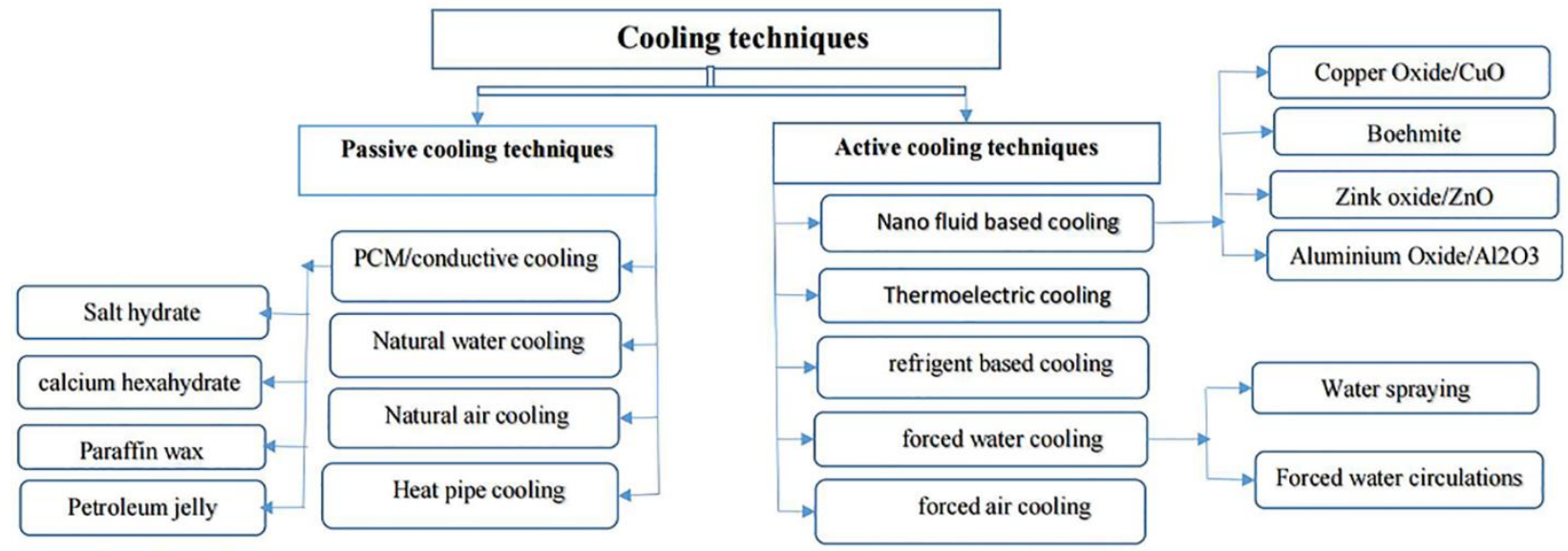

Figure 4 the classification of the primary cooling techniques.

power output and efficiency. The water droplets experiment on two identical polycrystalline solar cells on [20], one of the PV solar modules is considered as reference, and the next is taken as experimental. The result of the research attested that the power output of the experimental PV solar module with water droplets is generated 137.9W. However, the reference PV module without water droplets is generated 130.2W within the specific period. Therefore, the PV module with droplets of water enhanced the power output by a percentage of 5.6\%. From this experimental study, for the polycrystalline PV modules, the temperature decreased by $1^{0} \mathrm{C}$ would be increased the voltage by $0.33 \%$. From the result, we summarized that the water droplets on the PV solar modules decrease the temperature and get colder of the PV modules, which made the solar energy generating system effective. On the other hand, experimentally investigated, the PV module with the rectangular fin, which is passive cooling removed the heat from the solar module by $155 \%$ and generated $10.8 \%$ power output compared with the references module [65].

\section{Water spraying technique}

Water spraying is a type of active cooling technique that is used solar-powered pumps and is sprayed on the PV panels. Based on the scientific evaluations, the water spraying angles $\left(90^{\circ}, 180^{\circ}, 360^{\circ}\right)$ are tested; the best angle to spray water is the nozzle model at 900 , since best for water consumption and film water uniformly on the surface of PV module [66]. By using this technique, the temperature is decreased up to $35^{\circ} \mathrm{c}$. Further, the research was carried out to improve the PV solar module electrical efficiency, and the study result attested that the electrical efficiency was enhanced by $15 \%$ in extreme environmental weather conditions [41]. However, the water spraying cooling technique consumes water; thereby, it is difficult to apply and infeasible in areas with a shortage of water, like deserts [22]. In the articles of $[67,68]$, the experimental research was conducted on pouring water on the PV solar modules surface using water film and rain imitation methods to cool the systems. From the experiment, the maximum cooling point by using water film is double of the rain imitation. The temperature reduction of the PV solar module during the experiment by using water film is $20^{\circ} \mathrm{c}$, whereas by using rain imitation is $10^{\circ} \mathrm{c}$. The cooled PV solar module power output using a water film cooling method increased by approximately 20\%. During the experiment, the maximum power generated by the chilled PV solar module is $125.5 \mathrm{~W} / \mathrm{m}^{2}$, while the uncooled PV module generated $105.3 \mathrm{~W} / \mathrm{m}^{2}$. The rain imitation for cooling of PV solar module has higher swashing and bouncing of water than the water film method. Therefore, the water film cooling method is more effective in cooling the PV modules than rain imitation. The water spraying technique improved the solar energy generation performance because it has additional benefits and cooling, such as evaporation and cleaning of the surface of PV modules [66].

\section{Forced water circulation technique}

The heat duct can be mounted on the rear side of the panels to minimize the operating temperature. The PV solar module performance relies on the heat transferring capacity of the pipe materials. According to [22], the cooled PV solar module has a significant temperature reduction of approximately $35.9^{\circ} \mathrm{c}$, and the power output improved by $14.29 \%$ at solar radiation of $1000 \mathrm{~W} / \mathrm{m}^{2}$ and $35^{\circ} \mathrm{c}$ of ambient temperature.

\section{Nanofluids based cooling technique}

Nanofluid cooling is the type of cooling, nanoparticles mix with different fluids/water, which is used to cool the PV solar panels and improve the solar energy generation systems efficiency [69, 70]. Nanofluids are prepared by two methods, such as the one-step method and the two-step method. The mass fabrication of Nanofluids could use the two-step method, while the one-step method has better dispersion characteristics. The cooling ability of Nanofluid depends on the materials of Nanoparticles, size of particles, and thermal conductivity of particles [71]. Some of the Nanoparticles are Aluminium oxide $\left(\mathrm{Al}_{2} \mathrm{O}_{3}\right)$, copper oxide (CuO), Magnetite $\left(\mathrm{Fe}_{3} \mathrm{O}_{4}\right)$,

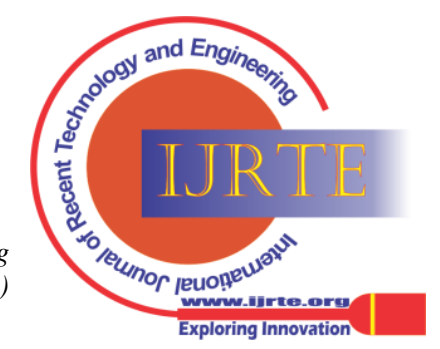




\section{Recent Improvements of the PV Solar Energy Generation Performance}

Zinc oxide ( $\mathrm{ZnO})$, and Silicone carbide (SiC). The $\mathrm{Co}_{3} \mathrm{O}_{4}$ /water cooling and $\mathrm{Al}_{2} \mathrm{O}_{3}$ /water Nanofluids cooling technique for the PV module has improved overall performance remarkably [72]. The tested result indicated that using 1\% Nanofluid/ Co3O4 + water for cooling improved by $10.91 \%$ electrical efficiency compared to the water-cooling technique [73].

\section{Phase change materials (PCM) technique}

Phase change materials (PCM) techniques are a passive cooling method with conductive cooling, which can absorb heat, normalize and uniform the PV solar modules temperature by changing the materials' physical state like during melting or freezing point [74, 75]. PCM materials are petroleum jelly material, Capric-lauric acid, Calcium hexahydrate, and salt hydrate. PCM has essential properties for solar energy generation systems, absorbing excess heat during the day and then releasing it at night. In the paper [76], an experimentally examined study attested that the highest temperature reduction difference on PV solar module with PCM is $35.6^{\circ} \mathrm{c}$ within one day testing time. The average PV solar module performance efficiency has also stepped up from $1.1 \%$ to $2.8 \%$. The PCM effects on the PV solar panels have been investigated in the article [77]. And the article state that the PCM material is used to improve the PV solar panels performance when the PV module temperature is higher than the PCM melting point unless the PCM materials work as an insulator, not as a heat remover. In article [77], the PCM materials (paraffin wax and sheep fat) are used to improve the PV solar module cooling performance; whereas, sheep were high efficient than paraffin wax.

\section{Thermoelectric cooling techniques}

Thermoelectric (TE) cooling is the type of active cooling based on the Peltier effect that is the direct conversion of temperature variation into electric voltage. The thermoelectric cooling techniques can remove heat from the solar panels and then transform it into electrical energy based on the See beck effect. The Peltier effect creates a heat flux at the joining point of two various kinds of materials. The movement rate of heating or cooling depends on the voltage and temperature difference. In the article [78] the authors investigated that the generated power of the paired PV-TEG module was higher than the pure PV module, without depending on the types of cooling and radiation applied. Thus, TE has dual functions, reducing heat from the solar panel surface and generating electrical energy by using heat energy generated by the PV solar module. The experimental result showed that the efficiency of PV-TE increased significantly since coating thermal interface materials reduced the thermal contact resistance. Therefore, the generated power with thermal interface materials increases by $14 \%$, whereas with TEG increases by $60 \%$ because of decreased thermal contact resistance.

\section{Hybrid/multi-concept cooling technique}

This type of cooling technique is a combination of the solar panel with different techniques, including thermal collectors, used to get better performance than common or traditional techniques [79]. From the article [16], the experimental investigation is taken on the twopolycrystalline PV solar panel to illustrate the overall performance with and without applying cooling technique under the same environmental weather conditions. The experiment is carried on for three days. The PV module with the cooling technique is mounted with a water jacket and the manufactured thermal collector on the rear side. Further, there is also a small-scale cooling tower is configured to remove the extracted heat. The study attested that the enhancement of the PV solar panel efficiency with the cooling technique, rather than the PV solar panel without the cooling technique.

The energy generation efficiency improved maximum by 2.5\% compared to the PV solar module without applying cooling technique. The hybrid cooling technique used water cooling and air cooling parallel. The tested result showed that the PV module efficiency with the cooling technique increased by $22.5 \%$ compared to the solar module without the cooling technique [80].

According to the article [79], the study is conducted in South Korea, and the researchers applied two cooling techniques on one PV module to compare with the reference module. The PV module is designed with the cooling technique of PV-TEC, which is mounted on the front side and rear side of the PV module, and there is a water tin film with a small DC pump. The result verified that the PV solar module efficiency, which cooling technique is applied, increased by $11.23 \%$, and the temperature is decreased by $21^{\circ} \mathrm{C}$ relative to the reference module. Furthermore, when PCM (Alumina powder) and 1\% Nanofluid cooling technique were applied to the PV solar module, the overall energy generation efficiency was enhanced by $4.52 \%$ [73]. Additionally, the experimental study result indicates that by mixing the $\mathrm{CuO}$ Nanoparticles with sheep fat of PCM, the maximum power output stepped up $24.6 \%$ to $26.2 \%$ relative to the PV solar module without cooling technique, and 5.3\% to $12 \%$ relative to the PV solar module with only PCM technique [77]. Therefore, the hybrid/multi-concept cooling technique is better for PV solar module performance than the single cooling techniques like only water cooling or only PCM cooling techniques. Therefore, we proposed it as a promising technique to get high efficient PV solar energy generating systems [72].

\section{b. Maximum power point tracking (MPPT) \\ techniques}

MPPT techniques are one of the promising techniques to regulate the PV solar module current and induced voltage, enhance the PV solar module efficiency, and maximize the output power.

The use of MPPT in the PV solar energy generation system is to get the maximum PV solar module power, since tracking current of maximum Power Point $\left(\mathrm{I}_{\mathrm{mpp}}\right)$ and voltage of maximum power point $\left(\mathrm{V}_{\mathrm{mpp}}\right)$ at different weather conditions [21, 81]. The power output variation and nonlinear characteristics of solar modules are other critical challenges in PV solar energy generation process. In the literature [21, 58], PV solar power output varies based on the rate of temperature and solar radiation variation due to weather conditions and other factors.

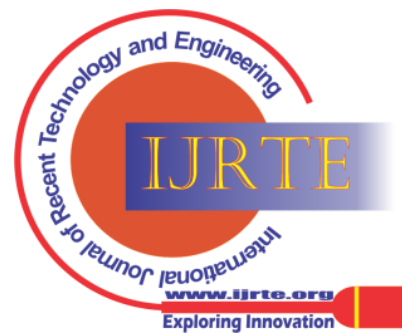


To improve this problem, from the type of DC-DC converters with MPP controller, the boost converter is connected to the system of PV solar energy generation [81]. Therefore, to improve the PV solar module efficiency and power output, the boost converter interfaced between the PV solar module and electrical appliances or load which use DC, even though it does not protect overcurrent. To overcome this shortage of boost converters, we have the chook converter (CUK converter), which is used to stabilize PV solar output voltage.

In general, we can classify the MPPT techniques as conventional and evolutionary based on the problem-solving performance to get sufficient PV solar energy systems efficiency and power output. Conventional MPPT techniques are, such as fractional open-circuit voltage (FOCV), fractional short circuit (FSC), perturb and observe (P\&O), incremental conductance(IC), hill climb (HC), ripple correlation (RC) and so on. Evolutionary MPPT techniques are, such as artificial neuro-fuzzy interface system (ANFIS), fuzzy logic controller (FLC), particle swarm optimization (PSO), neural network (NN), and cuckoo search (CS). The evolutionary MPPT techniques are new methods developed by using an algorithm, which is from artificial intelligence, and they have better efficiency. Evolutionary MPPT techniques are preferable than conventional MPPT techniques since evolutionary algorithms are the ability to handle the nonlinear behavior of PV solar energy systems. Different MPPT techniques are being discovered, and each of the techniques has its advantages, applications, and limitations [82, 83]. The MPPT techniques can be classified as follows, in the Fig.5.

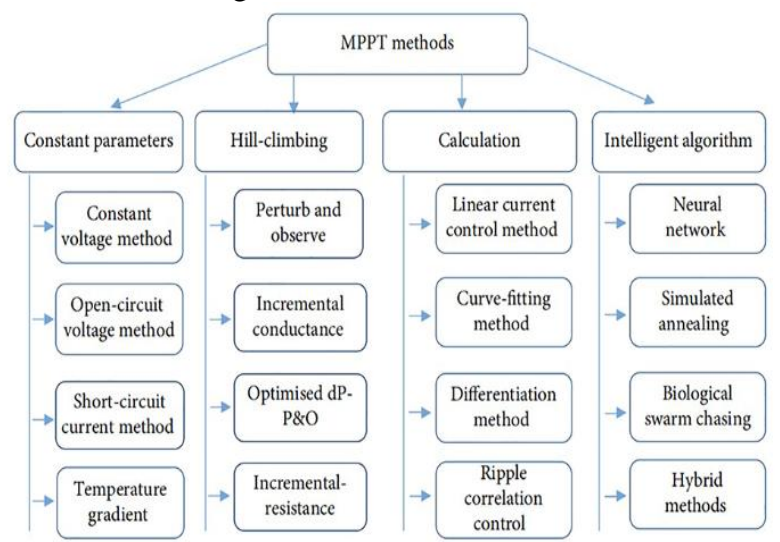

Figure 5 the classification of the MPPT methods [58].

From the article[58], The best MPPT techniques are chosen based on the following view of points. Such as Efficiency: techniques that have practical application.

Sensors: the technique must contain a limited and sufficient amount of sensors. PV solar modules have temperature sensors, solar radiation sensors, voltage sensors, and current sensors.

Implementation: some techniques are simple to implement, like constant voltage or constant current. Some others are complex, and they are based on evolutionary algorithms or artificial intelligence. Cost: it depends on the complexity or simplicity of the circuit of the method. In article [14], the best-suited solution for optimizing the maximum energy from PV solar system is Artificial intelligence (AI) - based MPPT techniques (like Fuzzy logic controller and artificial neural networks). The authors of [14] raised a constructive idea about the AI-based MPP techniques; however, these techniques are not a perfect solution to harnessing the maximum power output from the PV modules. When we see specifically, the AI-based MPPT techniques have their limitations. The limitation of the Fuzzy logic controller technique is that it can't alter when the rules are set once. Moreover, the tracking of MPP in this method without a well-skilled operator is inaccurate because the FLC function depends on the operator's ability [21]. The Artificial Neural Network (ANN)[84] is also an AI-based method with having multilayer perceptrons (MLP) such as an input layer that collects inputs, a hidden layer, and an output layer that issues outputs. It also has positive effects on handling the nonlinearity behavior of PV solar modules and on the onward movement of the techniques used to improve the PV solar energy generation. Even if there is a limitation, which needs much data since its architecture or topology has multilayers used in artificial neural network to track the MPP.

\section{c. Types of materials $P V$ panels made by}

Different researches and developments are on-going on the manufacturing of solar cells to achieve better power output and efficiency of solar energy harnessing systems [83-87]. Mainly, the PV solar modules efficiency is decided by two factors: PV solar cell efficiency and total PV solar module efficiency. PV solar cell efficiency rely on the structure of the cell and silicon material used (either P-type or N-type). While, total PV solar module efficiency relies on the configuration of cells, layout of the cells, and size of the panel. Total PV solar module efficiency is determined under standard test conditions, which means solar irradiance of $1000 \mathrm{~W} / \mathrm{m}^{2}$, Air Mass of 1.5 and cell temperature of $25^{\circ} \mathrm{C}$.

In the article [5], the first-generation PV solar modules (Crystalline silicon (c-Si)) are made from silicon materials that make them more affordable and highly efficient than other materials. And continuously improved its efficiency and power output over the last many years. The average efficiency of multi-crystalline and monocrystalline PV modules was $13.2 \%$ and $14.7 \%$ in 2016 , respectively. Due to many improvements, their efficiency reached $17 \%$ and $18 \%$ in 2019, respectively, and they controlled the PV modules markets, the detail about the PV solar module technology status in the market is shown in the Fig.6. In the literature [5, 88-91], A PERC cell (passivated emitter and rear contact) uses advanced silicon cell architecture having an additional layer known as a dielectric passivation layer on the back part of the traditional (Crystalline silicon) solar cells.

And that is used to get higher energy conversion efficiency and enhancing light absorption at longer wavelengths. The dielectric passivation layer increases the PV solar energy generation efficiency by reducing electron recombination, increasing absorption of solar radiation, and enabling higher internal reflectivity. With steady improvements over the years, now the PERC modules have an efficiency of $0.4 \%$ to $1 \%$ higher than that of conventional modules (Crystalline silicon). The PERC module is structurally nearly the same as other silicon modules. However,

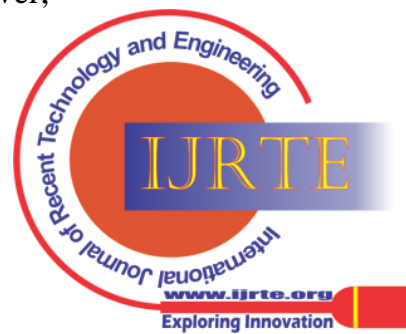




\section{Recent Improvements of the PV Solar Energy Generation Performance}

it is more costly than Crystalline silicon modules because of new passivation and rear contact capping layers. These modules are becoming popular within a short period so that they will dominate the PV market share up to 70\%, and it will reduce the cell thickness from the present $180 \mu \mathrm{m}$ to $\begin{array}{lllll}\text { nearly } & 150 \mu \mathrm{m} & \text { within } & 7 & \text { years. }\end{array}$

\section{Solar PV Technology Status}

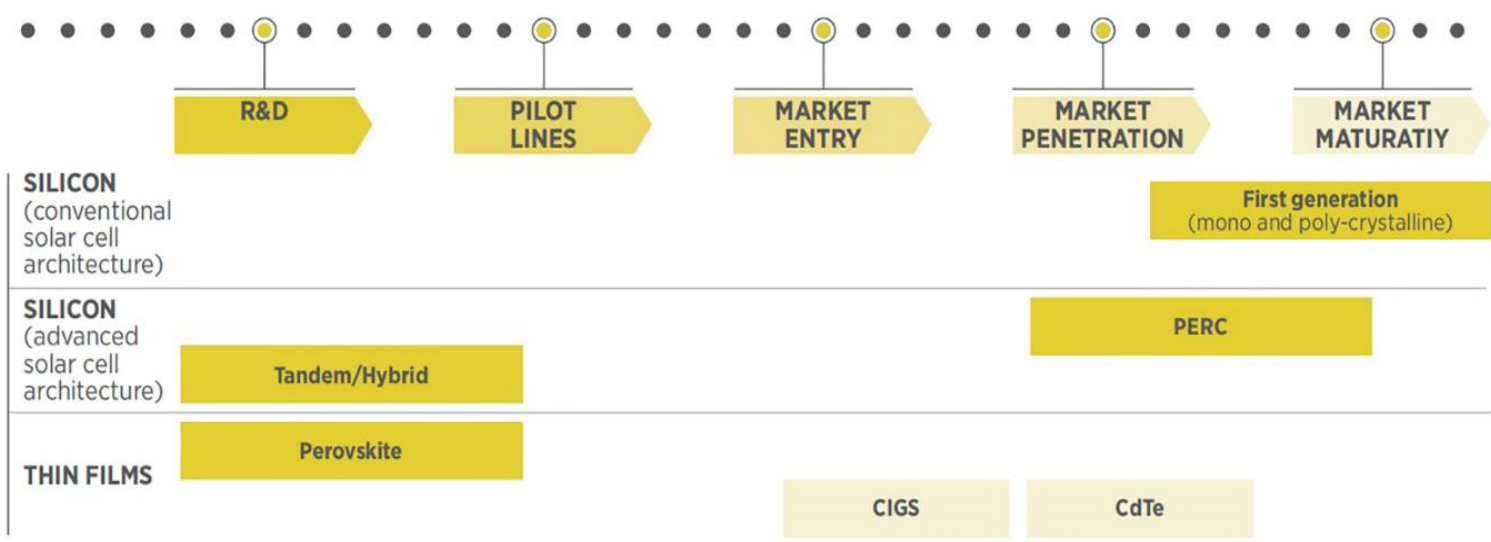

Figure 6 the status of the PV solar technologies [5].

Nomenclature: CIGS = copper-indium-gallium-diselenide, $\mathrm{CdTe}=$ cadmium telluride, $\mathrm{PERC}=$ passivated emitter and rear cell or contact.

In literature [5, 92], Tandem/Hybrid solar cell is also one of the kinds of PV solar panels formed by stacking different PV layers, one on others used for energy conversion across a broader spectral scope and to increase the absorption of photons. Each layer with different bandgaps has accountable for converting sunlight into electrical energy beyond Shockley-Queisser Efficiency Limit/SQ Limit. Tandem solar cells are made from organic, inorganic, and hybrid [93] For example, the combination of the monocrystalline dyesensitized solar cell (DSSC) layer on top of a copper indium gallium selenide (CIGS) thin-film bottom cells. The tandem/hybrid solar cell converts $45.1 \%$ to $46 \%$ of the solar light into electricity. Therefore, the tandem solar cells fabrication technique is used to get the most efficient solar cell in the world. Researchers have published various ideas, and they demonstrated experiments to improve the efficiency of tandem solar cells, and they have got a positive result. Nevertheless, some papers recommend that increasing the layers thickness to enhance the efficiency of tandem solar cells. Still, it is not a solution because increasing the materials thickness also increased the cost of the solar modules [93, 94]. The challenges in tandem/hybrid modules are that the materials used to manufacture are expensive, the complexity of the fabrication mechanism, and the instability of the systems due to the variation of climate conditions. Another promising material for solar cells is perovskites solar cells (PSCs), which have a high ability to absorb sunlight [95, 96]. For the first time, in 2009, the PSCs PV cell converted 3.8\% sunlight into electricity. But, now their efficiency is more than $25.2 \%$ since they have good electrical properties and fast improvements because crystals are easy to manufacture [97]. However, the PSCs did not get market maturity yet, because there are limitations like durability problems so that if their problems are solved, they will become economical PV solar cells [5, 98].

\section{d. Cleaning techniques}

Cleaning is one of the crucial techniques to enhance the PV solar module's power conversion performance. However, the dust accumulation on the surface of the solar panel's reduces the efficiency and life span [99]. Therefore, the cleaning techniques are classified as; Natural cleaning techniques, manual cleaning techniques, and automatic cleaning techniques [36]. The detailed classification of the cleaning techniques are described in the Fig.7.

\section{Manual cleaning techniques}

The Manual cleaning techniques have some disadvantages, such as cracking the PV solar panels during brushing, need a lot of labor and time, and cannot clean perfectly especially small particles that might be left on the surface of the panels [35].

\section{Natural cleaning techniques}

The PV solar modules are also cleaned by a natural technique like rain and wind; nevertheless, they negatively impact PV modules. For example, in desert areas, the wind will increase dust accumulation. Furthermore, heavy rain may not clean thoroughly, and it will make scratches on the surfaces of the module [36].

\section{Automatic/self-cleaning techniques}

The automated cleaning techniques need power generated by PV solar systems and effectively reduce the soiling effect. According to [100], the cleaning technique based on the water spraying and semi-automatic operation is tested, the performance for the reiteration of swept of 10, 20, and 30 times gained $57.0 \%, 79.1 \%$, and $86.7 \%$ of the initial clean PV solar module and the power conversion efficiency increased from $0.99 \%$ to $1.56 \%$.

The self- cleaning technique is the best method to clean the PV solar modules surface. It uses self-cleaning Nanofilms, which means coating the chemicals on the PV solar module surfaces [36]. Self-cleaning techniques effectively remove the dust accumulation for a big tilt angle due to sliding down by the force of gravity [101]. For the PV solar generation with a large scale, the self-cleaning technique like coating with hydrophobic is economically feasible since it doesn't need energy and it doesn't cause any crack on the PV solar modules.

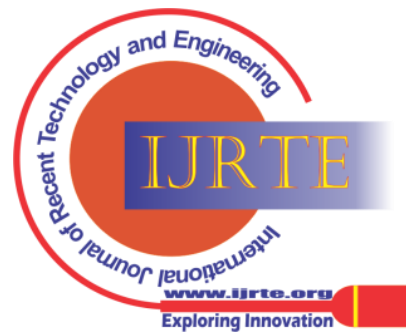


In the article [35], the experimental study is carried on three similar PV solar modules; the first module is coated with hydrophobic $\mathrm{SiO} 2$ nanomaterials, the second module is uncoated but cleaned manually. And the third module is dusty and uncleaned during an experimental time and used as a reference. The first self-cleaning hydrophobic $\mathrm{SiO} 2$ nanoparticle-coated modules increase the power output by

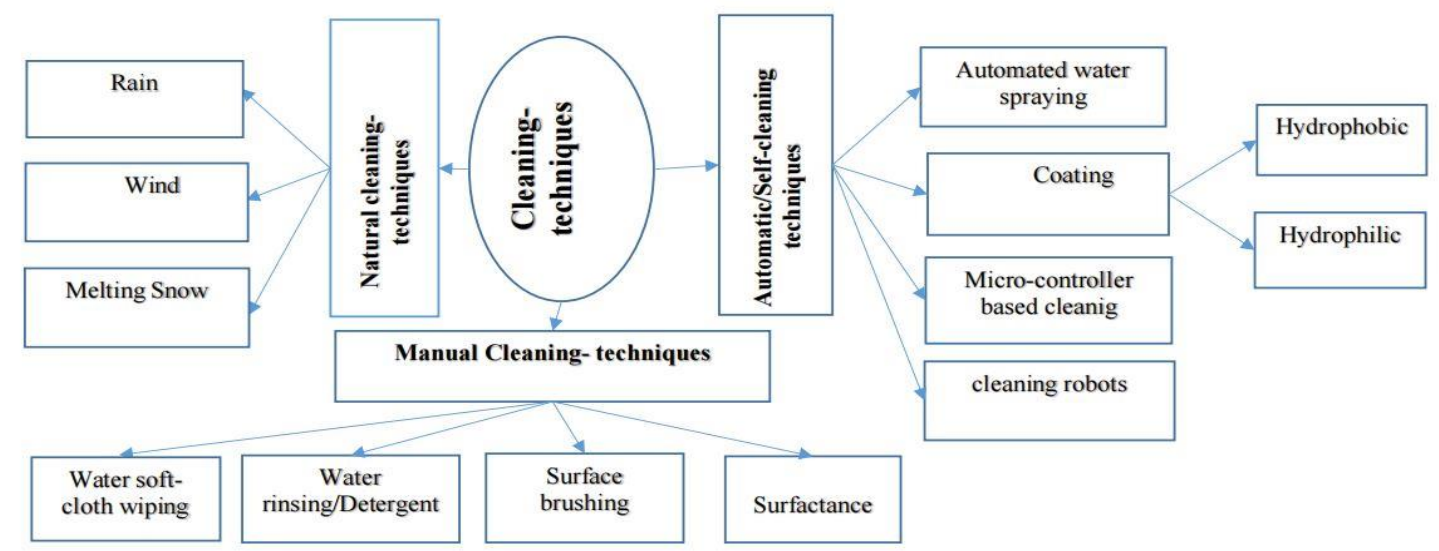

Figure 7 classification of the cleaning techniques.

$15 \%$ relative to the third dusty module or reference module. It is power output improvement also more remarkable than the second/uncoated module by $5 \%$. In contrast, the second or uncoated module, cleaned manually, improved its power output by $10 \%$ relative to the reference module. Thus, the experimental result attested that using hydrophobic $\mathrm{SiO} 2$ nanoparticle coating gave better overall efficiency of PV solar generation systems, and it doesn't need extra energy and time. The experiment demonstrated different kinds of dust like powder, sand, and other dust have different levels of effects on the PV solar modules. But the degradation amount of power output and efficiency of superhydrophobic coated PV solar modules are more petite than bare PV solar modules. The super-hydrophobic coating decreases the accumulation rate of dust since have low micro-Nano surface structures and low surface energy [25]. Therefore, super-hydrophobic coating with microNanoparticles is the best technique to reduce dust accumulation on PV solar panels. It enhanced the dust removing ability by $15.3 \%$ rather than coating by other particles [99]. Furthermore, the super-hydrophobic coating technique has better performance in reducing dust accumulation in high-altitude areas [101]. Hence, a coated glass of PV modules has better spectral transmittance, power output, and energy conversion efficiency after dust accumulation than the uncoated glass of PV modules [99].

\section{SUGGESTIONS AND RECOMMENDATIONS}

Energy is an essential thing for human beings in the world; without it the world is nothing. Nevertheless, uses of conventional energy such as coal and fuel are the main sources of the challenges through the world, since they pollute the environment and affect the food production process and health of human beings. Due to this, researchers and scholars encourage renewable energy generation to prove the continuity of life on earth. PV solar energy generation is an environmental friend and developed very rapidly. However, the PV solar module power output and efficiency are insufficient even though many improvements are being made. The PV solar module power output and efficiency are directly related to solar cell efficiency. So that, increasing the PV solar cell efficiency is fundamental for competitive PV solar module manufacturing because it directly decreases the cost of the manufacturing of PV solar cells by reducing the quantities and size required to get the desired output.

Therefore, if the efficiency level of the PV solar panels is high, the cost of the solar energy generation systems will reduced. Furthermore, it reduces the number of PV panels required to be transported to the solar power plant site, the area needed to be covered, the length of wires and cables [5, 102]. Therefore, based on the existed literature, the authors of this review suggested the following points on the future studies of the PV solar modules efficiency and power output improvements:- The MPP tracking serves to enhance the efficiency of PV solar module and the stability of the electrical networks. The power output fluctuates because of the variation of the solar radiation and temperature; the MPPT controller is connected with the solar energy generating system responsible for the PV solar module to work linearly to produce the maximum power. Some factors that affect the PV solar system's performance cannot be eradicated because they exist naturally. At the same time, the method of extracting the maximum power by using the MPPT technique can enhance the performance and increase the life span of the PV solar panels even under these factors [103]. However, the conventional technique has accuracy limitations, so the researchers need to study more on the maturity of the artificial intelligence-based MPPT like fuzzy logic algorithm. Nevertheless, it is a promising technology to improve the PV solar energy system performance [81]. AI-based MPPT algorithms can handle the nonlinearity of the PV solar energy and fast-tracking of maximum power point with small power oscillations [82, 83]. The innovation of new technology on the PV solar panel is on-going from period to period and is being improved rapidly, however, didn't reach the sufficient efficiency level of generating energy from the sunlight yet [93, 104]. 


\section{Recent Improvements of the PV Solar Energy Generation Performance}

The best PV solar cell development quality is highly related to achieving the sufficient efficiency of PV solar energy systems. Therefore, the PV solar modules plays a great role in improving the PV solar energy generating system's performance. Therefore, the manufacturers and researchers need further study the relationship between environmental factors and solar cells. Based on the relationship, manufacturers have to identify the suitable technology with selected solar cells for that area's weather condition to harness the maximum power output.

Researches on the improvement and development of PV solar energy efficiency is conducted lonely by academicians or manufacturers, and this is one of the challenges facing the area. However, when working cooperatively, the progress may be fast. Moreover, it will give the desired outcomes within a short time and with minimum cost, since in the togetherness there are the strengths and complement the weakness of one another. So, for the future, the authors recommend that the researchers and manufacturing institutions work cooperatively.

Based on the recent research trend, the manufacturers and researchers try to find the solution for one problem or factor except some of them. Still, many other factors that caused the decrease of the PV module's efficiency are lifted. This trend may take too much money and time to overcome all problems and give a solution for all factors. Hence, future studies have to filter out all factors that influence the PV solar energy generation performance, then will focus on looking for the solutions to each problem parallel. Then can guarantee stability and sustainability and improve the PV solar energy generating system's overall performance.

The researchers and manufacturers investigate many techniques to improve the PV solar energy efficiency, and some techniques have multipurpose or known as hybrid technique. For instance, PV solar modules cooling by using water is one of the effective techniques to improve the power output and efficiency. In addition to that, the continuous flowing or spraying of cold water on the PV solar module surface is used to remove dust accumulation, clean, reduce soiling, and so on. Therefore, applying the multipurpose techniques on the PV solar modules gives better performance. For the future desired to study more about the applications of multipurpose technique on the PV solar energy systems $[6,79,80]$.

\section{CONCLUSION}

In this article, the authors reviewed the recent literature on improving the PV solar energy generation efficiency and power output. In the renewable energy sectors, PV solar energy is a significant and resilient source of power through the world for the future. It grows at a very high rate, and its cost also decreasing. PV solar energy is sustainable (rely on sunlight), reliable, has less maintenance, and does not cause any pollutions. PV solar energy generation systems can be applicable for various situations, such as domestic and commercial purposes. However, PV solar energy systems have still confronting efficiency problems, even though there are better improvements. The literature on improving efficiency and power generation quality level of the PV solar modules has been reviewed. The environmental factors and natural phenomena that affect the PV solar module's performance are filtered out. Based on the existed studies and experimental results, the solutions for the problems are presented. Better techniques for enhancing the PV solar energy system's overall performance are proposed and based on the current efficiency status, the suggestion and recommendations are forwarded for further studies.

\section{Declaration of the Conflicts of interest}

The authors declared that no conflict of interest.

\section{APPENDIX}

Graphical Abstract of the PV Solar Energy Generation Performance Improvements. Fig.8.

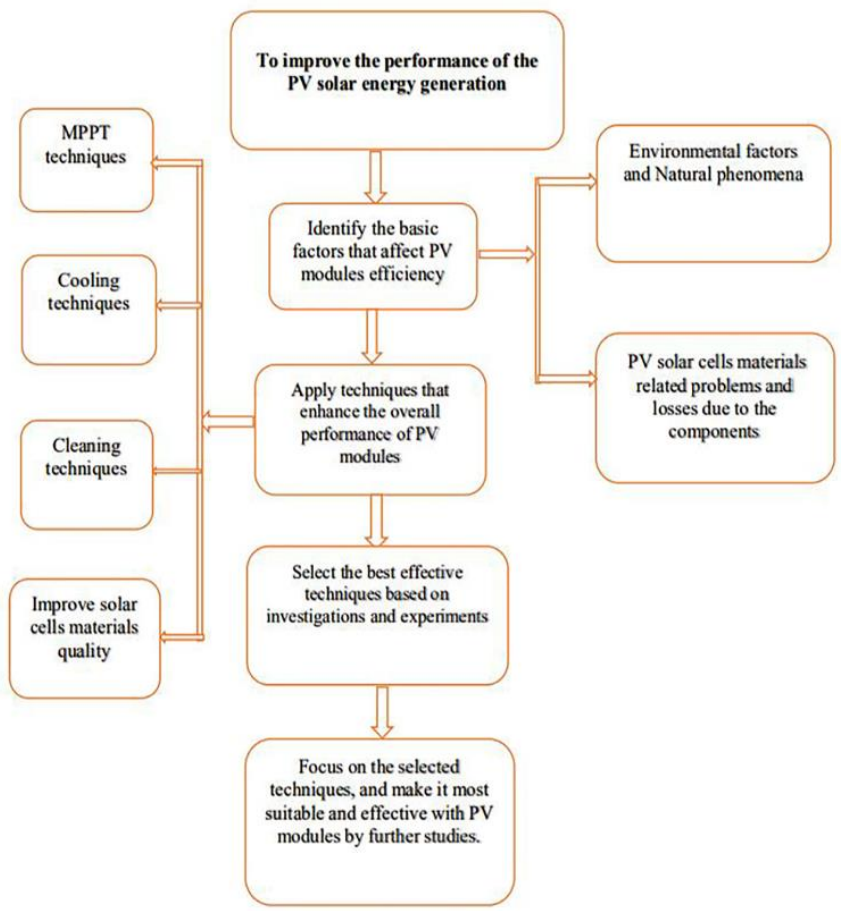

Figure 8 Graphical Abstract

\section{ACKNOWLEDGMENT}

The authors are grateful to take this chance to give our deep gratitude to our All-powerful God, for his endless blessing and kindness in all our life. We would also convey our thanks to Professor. Jianwu Yu, for his continuous supervision and motivational advice. We would like to thank our friend, Dr. Girum Girma, for his encourageous idea and constructive advice. Furthermore, the authors would acknowledge the Hunan University to gave this scholarship opportunity to study in this huge university.

\section{REFERENCES}

1. H, A., A. M. A, A. A. Ahmed, K. M. J, A. H. Hassan, et al. Generating Power from Solar Sphere Design. in 2019 Advances in Science and Engineering Technology International Conferences (ASET). 2019.1-4.

2. Abdulmouti, H., K. Ali, A. Ali, M. Ali, S. Abdullah, et al. Smart innovation applications for a green house using sustainable and renewable energy in the UAE: Home energy retrofit. in 2018 Advances in Science and Engineering Technology International Conferences (ASET). 2018.1-6.

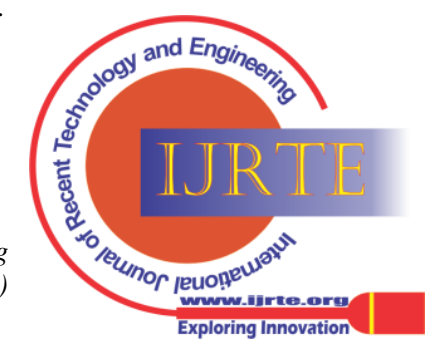


3. Pawluk, R.E., Y. Chen, and Y. She, Photovoltaic electricity generation loss due to snow - A literature review on influence factors, estimation, and mitigation. Renewable and Sustainable Energy Reviews, 2019. 107: 171-182.

4. IEA, World Energy Outlook 2020. 2020, IEA(2020): Paris. 3-457.

5. Dolf Gielen, R., E. Gorini, G. Asmelash, R. Prakash, G. Leme, et al., Future of Solar Photovoltaic: Deployment, investment, technology, grid integration and socio-economic aspects (A Global Energy Transformation: paper). 2019, International Renewable Energy Agency(IRENA): Abu Dhabi. 1-73.

6. Idoko, L., O. Anaya-Lara, and A. McDonald, Enhancing PV modules efficiency and power output using multi-concept cooling technique. Energy Reports, 2018. 4: 357-369.

7. Mousavi, S.A., S. Safavi, A. Naderlou, H. Shahmohammadi, S. Moshfegh, et al. Important Solar Parameters in Installing Solar Cells Case study of Zanjan city in Iran. in 2018 5th International Conference on Renewable Energy: Generation and Applications (ICREGA). 2018.107-111.

8. Wani, C. and K. Gupta. Towards improving the performance of solar photovoltaic energy system: A review. in IOP Conference Series: Earth and Environmental Science. 2019.1-7.

9. Issa Naji, A., K. Abdulhussein Hafedh, and K. Idan Fadheel. Increasing the solar cell efficiency using glass balls. in Journal of Physics:International Laser Technology and Optics Symposium 2019 (iLATOS2019) 2020. Senai, Malaysia: IOP Publishing.1-7.

10. Mughees, M., M. Sadaf, S. Khan, A. Rasheed, K. Daniel, et al. Impact of Shading, Dust Accumulation and Temperature rise on the International Symposium on Recent Advances in Electrical Engineering \& Computer Sciences (RAEE \& CS). 2020. Islamabad, Pakistan: IEEE.1-6.

11. (EIA), E.I.A., Annual Energy Outlook 2020 with projections to 2050. 2020, U.S. Energy Information Administration(EIA):

12. Hasani, A.H., S.F. Abdullah, A.W.M. Zuhdi, M.S. Bahrudin, F. Za'abar, et al. Modelling and Simulation of Photovoltaic Solar Cell using Silvaco TCAD and Matlab Software. in 2018 IEEE 2018.214-217.

13. Yan, C., M. Qu, Y. Chen, and M. Feng, Snow removal method for self-heating of photovoltaic panels and its feasibility study. Solar Energy, 2020. 206: 374-380. Photovoltaic Power Generation Using Improved MPPT Method. in 2020 International Congress on Human-Computer Interaction, Optimization and Robotic Applications (HORA). 2020.1-4.

15. Ghosh, A., Soiling Losses: A Barrier for India's Energy Security Dependency from Photovoltaic Power. Challenges, 2020. 11(1): 122.

16. Karunasena, U.T.R.K., M.A.P. Karunarathna, D.G.A.S. Kumara, M.M.I.D. Manthilake, and H.K.G. Punchihewa. Efficiency Improvement of Solar Photovoltaic Thermal Systems by Experimental and Numerical Analysis. in 2020 Moratuwa Engineering Research Conference (MERCon). 2020.488-493.

17. Samal, K.B. and A. Bisoyi. Investigation of Environmental Effects on the Performance of Solar PV Modules. in 2020 International Conference on Emerging Frontiers in Electrical and Electronic Technologies (ICEFEET). 2020.1-5

18. Herez, A., H. El Hage, T. Lemenand, M. Ramadan, and M. Khaled, Review on photovoltaic/thermal hybrid solar collectors: Classifications, applications and new systems. Solar Energy, 2020. 207: 1321-1347.

19. Raina, G. and S. Sinha, Outlook on the Indian scenario of solar energy strategies: Policies and challenges. Energy Strategy Reviews, 2019. 24: 331-341.

20. Mustafa, R.J., M.R. Gomaa, and M. Al-Dhaifallah, Environmental Impacts on the Performance of Solar Photovoltaic Systems. Sustainability, 2020. 12(2): 1-17.

21. Rani, H.B.C.C., Different Conventional and Soft Computing MPPT Techniques for Solar PV Systems with High Step-Up

22. Boost Converters: A Comprehensive Analysis. Energies 2020. 13(2): 1-27.

23. Sheikh, Y., A. Butt, K. Paracha, A. Awan, A. Bhatti, et al., An improved cooling system design to enhance energy efficiency of floating photovoltaic systems. Journal of Renewable and Sustainable Energy, 2020. 12(5): 1-18. aeini, M. and A. salemnia. Techno-Economic Feasibility Analysis of a Grid-Connected Photovoltaic Power Plant in Shahid Beheshti University, Iran. in 2019 Iranian Conference on Renewable Energy \& Distributed Generation (ICREDG). 2019.1-6. Performance of Solar PV: The Case of Pakistan. in 2020 Washington, DC 20585. 1-81. International Conference on Semiconductor Electronics (ICSE).

14. Kareem, M.F. and S. Kurnaz. Improving the Efficiency of Solar

24. Myasnikova, T.V., A.A. Kirillova, S.P. Ivanova, O.V. Sveklova, and O.A. Nadezhdina. Simulation of Solar Energy Photovoltaic Conversion. in 2020 International Youth Conference on Radio Electronics, Electrical and Power Engineering (REEPE). 2020.1-4.

25. Lu, H., R. Cai, L.-Z. Zhang, L. Lu, and L. Zhang, Experimental investigation on deposition reduction of different types of dust on solar PV cells by self-cleaning coatings. Solar Energy, 2020. 206: 365-373.

26. Manoj Kumar, N., S. Chopra, A. Oliveira, H. Ahmed, S. Vaezi, et al., Solar PV module technologies. 2020. 51-78.

27. Abdulhady, H., H. Metwally, and T. Abdul fattah, Review of the Factors Affecting the Solar Energy Yield in Egypt. Egyptian Journal for Engineering Sciences and Technology, 2020. 29(Electrical Engineering): 51-60.

28. Kumar, A. and S. Lal, Thermodynamic analysis of Factors affecting the Performance of Solar Collectors, in International Conference \& Expo on "Advances in Power Generation from Renewable Energy Sources (APGRES 2017). 2017: GEC Banswara, India. 176-181.

29. Kim, B., Solar Energy Generation Forecasting and Power Output Optimization of Utility Scale Solar Field, in Mechanical Engineering. 2020, California Polytechnic State University: San Luis Obispo. 1-99.

30. Muhmmad Sulman , M.A., Sanaullah Drigh, Impact of Environmental Factors on Solar Photovoltaic Module and Different Material Employed on it. International Journal of Engineering Research \& Techmology (IJERT), 2020. 09(08): 623-630.

31. Ghosh, S., V.K. Yadav, and V. Mukherjee, Impact of environmental factors on photovoltaic performance and their mitigation strategiesA holistic review. Renewable Energy Focus, 2019. 28: 153-172.

32. Brecl, K., M. Bokalič, and M. Topič, Annual energy losses due to partial shading in PV modules with cut wafer-based Si solar cells. Renewable Energy, 2021. 168: 195-203.

33. Olisa, S., O. Oparaku, E. Anoliefo, and M. Eze, Factors Affecting Rooftop PV Module Systems, in 1st International Conference of Centre for Lion Gadgets and Technologies (LGT-UNN). 2019: University of Nigeria, Nsukka.

34. Mahmood, Y., F. Atallah, and A. Youssef, Tikrit Journal of Pure Science Studying the weather condition affecting on solar panel efficiency. Tikrit Journal of Pure Science, 2020. 25(3): 98-102.

35. Alamri, H.R.R., H.; Abd-Elbary, H.; Ziedan, H.A.; Elnozahy, A., Experimental Investigation to Improve the Energy Efficiency of Solar PV Panels Using Hydrophobic SiO2 Nanomaterial. Coatings, 2020. 10(5): 2-14.

36. Ayaz, A., H. Ahmad, F. Ahmad, A. Khan, S.M. hasnain Tarmazi, et al. Self-cleaning of glass surface to maximize the PV cell efficiency. in 3rd Pak-Turk International Conference on Emerging Technologies in the field of Sciences and Engineering (ETSE) 2020. GIK Institute, Topi, Pakistan: IOP Publishing.1-15.

37. Karthikeyan, V., C. Sirisamphanwong, S. Sukchai, S.K. Sahoo, and T. Wongwuttanasatian, Reducing PV module temperature with radiation based PV module incorporating composite phase change material. Journal of Energy Storage, 2020. 29: 1-12.

38. Hanifi, H., M. Pander, U. Zeller, K. Ilse, D. Dassler, et al., Loss analysis and optimization of PV module components and design to achieve higher energy yield and longer service life in desert regions. Applied Energy, 2020. 280: 1-12.

39. Das, M.R., Effect of Different Environmental Factors on Performance of Solar Panel. International Journal of Innovative Technology and Exploring Engineering (IJITEE), 2019. 8(11): 1518.

40. Stanka, N., A. Aboltins, and J. Palabinskis. Impact of high temperature and other factors on pv module efficiency on small farms in Latvia. in 19th International Scientific Conference Engineering for Rural Development. 2020. Engineering for Rural Development.472-480.

41. Dwivedi, P., K. Sudhakar, A. Soni, E. Solomin, and Kirpichnikova, Advanced cooling techniques of P.V. modules: A state of art. Case Studies in Thermal Engineering, 2020. 21: 1-17.

42. Tarigan, E., The Effect of Dust on Solar PV System Energy Output Under Urban Climate of Surabaya, Indonesia. Journal of Physics: Conference Series, 2019. 1373: 1-7.

43. Liu, X., S. Yue, J. Li, and L. Lu, Study of a dust deposition mechanism dominated by electrostatic force on a solar photovoltaic module. Sci Total Environ, 2021. 754: 1-13.

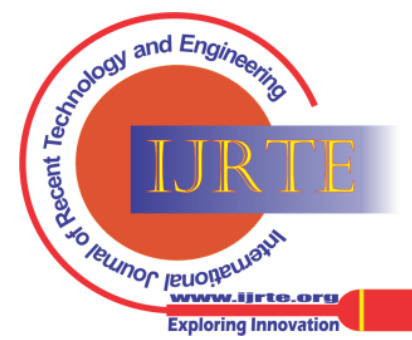




\section{Recent Improvements of the PV Solar Energy Generation Performance}

44. Maharana, S.M., A. Mohapatra, C. Saiprakash, and A. Kundu. Performance Analysis of Different PV Array Configurations under Partial Shading Condition. in 2020 International Conference on Computational Intelligence for Smart Power System and Sustainable Energy (CISPSSE). 2020.1-5.

45. Chanchangi, Y.N., A. Ghosh, S. Sundaram, and T.K. Mallick, An analytical indoor experimental study on the effect of soiling on PV, focusing on dust properties and PV surface material. Solar Energy, 2020. 203: 46-68.

46. Sisodia, A.K. and R.k. Mathur, Impact of bird dropping deposition on solar photovoltaic module performance: a systematic study in Western Rajasthan. Environmental Science and Pollution Research, 2019. 26(30): 31119-31132.

47. Choi, J.h., J. Hyun, W. Lee, B.-G. Bhang, Y.K. Min, et al., Power performance of high density photovoltaic module using energy balance model under high humidity environment. Solar Energy, 2021. 219: 50-57.

48. Lorenzi, B., M. Acciarri, and D. Narducci, Experimental Determination of Power Losses and Heat Generation in Solar Cells for Photovoltaic-Thermal Applications. Journal of Materials Engineering and Performance, 2018. 27(12): 6291-6298.

49. Hanifi, H., B. Jaeckel, and J. Schneider, Simulation of Optical and Electrical Losses of PV Modules in Moderate and Desert Conditions. 2019. 1255-1259.

50. Tachikawa, M., Y. Nozaki, T. Nishioka, and T. Yamada, Enhancement of PV Module Efficiency Using Reduced ReflectionLoss Surface. 2020. 2110-2112.

51. Muhfidin, R. and I. Yu. Thermal Analysis of PV Module and the Effect on its Efficiency. in 2019 International Conference on Technologies and Policies in Electric Power \& Energy. 2019.1-4

52. Kumar, R., V. Deshmukh, and R. Bharj, Performance enhancement of photovoltaic modules by nanofluid cooling: A comprehensive review. International Journal of Energy Research, 2020. 44(8): 6149-6169.

53. Clavijo Blanco, J., G. Alvarez-Tey, N. Saborido-Barba, J. Barberá González, C. García-López, et al. Quality inspection of a 2.85 MW PV power plant under mismatch loss due to different classes of PV module installed. in 18th International Conference on Renewable Energies and Power Quality (ICREPQ'20). 2020. Granada (Spain): Renewable Energy and Power Quality Journal.276-281.

54. Muneeshwaran, M., U. Sajjad, T. Ahmed, M. Amer, H.M. Ali, et al., Performance improvement of photovoltaic modules via temperature homogeneity improvement. Energy, 2020. 203: 1-13.

55. Gunji, R.M., G.R.S. Mattos, C.D.S. Bordon, L.A. Gómez-Malagón, and L.R.P. Kassab, Efficiency enhancement of silicon solar cells covered by $\mathrm{GeO} 2-\mathrm{PbO}$ glasses doped with Eu3+ and $\mathrm{TiO} 2$ nanoparticles. Journal of Luminescence, 2020. 223: 1-6.

56. Shin, D.H., C.W. Jang, J.S. Ko, and S.-H. Choi, Enhancement of efficiency and stability in organic solar cells by employing MoS2 transport layer, graphene electrode, and graphene quantum dotsadded active layer. Applied Surface Science, 2021. 538: 1-6.

57. Chen, M., S.R. Sahamir, G. Kapil, A.K. Baranwal, M.A. Kamarudin, et al., Inverted CsPbI2Br perovskite solar cells with enhanced efficiency and stability in ambient atmosphere via formamidinium incorporation. Solar Energy Materials and Solar Cells, 2020. 218: 1-

58. Cotfas, D.T. and P.A. Cotfas, Multiconcept Methods to Enhance Photovoltaic System Efficiency. International Journal of Photoenergy, 2019. 2019: 1-14.

59. Wahab, A., M. Khan, and A. Hassan, Impact of Graphene Nanofluid and Phase Change Material on Hybrid Photovoltaic Thermal System: Exergy Analysis. Journal of Cleaner Production, 2020. 277: 1-17.

60. Wisam K. Hussam, A.A., Gergory J. Sheard, Efficiency Enhancement of Photovoltaic Panels Using an Optimised Air Cooled Heat Sink. World Academy of Science, Engineering and Technology, 2020. 14(7): 196-202.

61. Navid Khordehgah, A.Ż.-G., Hussam Jouhara, Energy Performance Analysis of a PV/T System Coupled with Domestic Hot Water System. ChemEngineering, 2020. 4(2): 1-14.

62. Teo, H.G., P.S. Lee, and M.N.A. Hawlader, An active cooling system for photovoltaic modules. Applied Energy, 2012. 90(1): 309-315.

63. Kalogirou, S., L. Aresti, P. Christodoulides, and G. Florides, The Effect of Air Flow on a Building Integrated PV-panel. Procedia IUTAM, 2014. 11: 89-97.

64. Jailany, A., Effect of Forced Air Cooling on Efficiency of Photovoltaic Module. 2019. 3: 773-786.

65. Amber, K.P., W. Akram, M.A. Bashir, M.S. Khan, and A. Kousar, Experimental performance analysis of two different passive cooling

techniques for solar photovoltaic installations. Journal of Thermal Analysis and Calorimetry, 2021. 143(3): 2355-2366.

66. Alberto Benato, A.S., An Experimental Investigation of a Nove Low-Cost Photovoltaic Panel Active Cooling System. Energies, 2019. 12(8): 1-24

67. Luboń, W., G. Pelka, M. Janowski, L. Pająk, M. Stefaniuk, et al. Assessing the Impact of Water Cooling on PV Modules Efficiency. in

6thScientificConferenceRenewableEnergySystems,Engineering,Tec hnology,InnovationICoRES2019. $2020 . \quad$ Krynica,Poland.: Energies.1-13.

68. Luboń, W., M. Janowski, G. Pelka, and P. Reczek, Analysis of the cooling of PV modules with water on their efficiency. E3S Web of Conferences, 2020. 154: 1-5.

69. Vaka, M., R. Walvekar, A.K. Rasheed, M. Khalid, and H. Panchal, A Review: Emphasizing the Nanofluids Use in PV/T Systems. IEEE Access, 2020. 8: 58227-58249.

70. Hussein, H.A., A.H. Numan, and R.A. Abdulrahman, Improving the Hybrid Photovoltaic/Thermal System Performance Using WaterCooling Technique and Zn-H2O Nanofluid. International Journal of Photoenergy, 2017. 2017: 1-14.

71. Suresh, A.K., S. Khurana, G. Nandan, G. Dwivedi, and S. Kumar, Role on nanofluids in cooling solar photovoltaic cell to enhance overall efficiency. Materials Today: Proceedings, 2018. 5(9, Part 3): 20614-20620.

72. Salem, M.R., M.M. Elsayed, A.A. Abd-Elaziz, and K.M. Elshazly, Performance enhancement of the photovoltaic cells using Al2O3/PCM mixture and/or water cooling-techniques. Renewable Energy, 2019. 138: 876-890.

73. Rajaee, F., M.A.V. Rad, A. Kasaeian, O. Mahian, and W.-M. Yan, Experimental analysis of a photovoltaic/thermoelectric generator using cobalt oxide nanofluid and phase change material heat sink. Energy Conversion and Management, 2020. 212: 1-15.

74. Singh, P., V. Mudgal, S. Khanna, T.K. Mallick, and K.S. Reddy, Experimental investigation of solar photovoltaic panel integrated with phase change material and multiple conductivity-enhancingcontainers. Energy, 2020. 205: 1-30.

75. Pichandi, R., K. Murugavel Kulandaivelu, K. Alagar, H.K. Dhevaguru, and S. Ganesamoorthy, Performance enhancement of photovoltaic module by integrating eutectic inorganic phase change material. Energy Sources, Part A: Recovery, Utilization, and Environmental Effects, 2020: 1-18.

76. Stropnik, R. and U. Stritih, Increasing the efficiency of PV panel with the use of PCM. Renewable Energy, 2016. 97: 671-679.

77. Siahkamari, L., M. Rahimi, N. Azimi, and M. Banibayat, Experimental investigation on using a novel phase change materia (PCM) in micro structure photovoltaic cooling system. International Communications in Heat and Mass Transfer, 2019. 100: 60-66.

78. Zhang, J., H. Zhai, Z. Wu, Y. Wang, H. Xie, et al., Enhanced performance of photovoltaic-thermoelectric coupling devices with thermal interface materials. Energy Reports, 2020. 6: 116-122.

79. Eid, A. and H. Seong-Gu, Using the Hybrid Cooling Techniques to improvement a Photovoltaic Module performance . Misr Journal of Agricultural Engineering, 2020. 37: 165-248.

80. Rickric, O., Hybrid Cooling System for Solar PV Panel International Journal of Emerging Trends in Engineering Research, 2020. 8: 4079-4083.

81. Başoğlu, M.E. Realization of a low cost and fast boost converter based MPPT for PV system. in 2019 4th International Conference on Power Electronics and their Applications (ICPEA). 2019.1-6.

82. Singh, R., S.K. Maurya, and S. Sarangi. Improved Performance of PV Module by combining two MPPT Techniques. in 2019 International Conference on Electrical, Electronics and Computer Engineering (UPCON). 2019.1-6.

83. Toodeji, H. and S. Aghaei, Domestic PV System with Feedback Linearization-Based Control Strategy for Module-Level MPPT under Partial Shading Condition. Journal of Modern Power Systems and Clean Energy, 2020: 1-10.

84. Barrera, J.M., A. Reina, A. Maté, and J.C. Trujillo, Solar Energy Prediction Model Based on Artificial Neural Networks and Open Data. Sustainability, 2020. 12(17): 1-21.

85. Lee, S., S. Lee, L. Ellis, A. Smith, and M. Lee, Design of Solar Panels Efficiency Monitoring System. 2020. 1-4

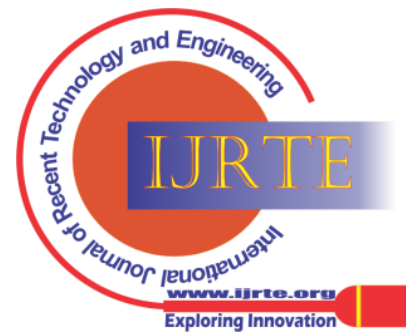


86. Telicko, J., D. Heincis, and A. Jakovics. A study of solar panel efficiency in Latvian climate conditions. in E3S Web of Conferences. 2020. Jelgavas 3, Riga, Latvia: EDP Sciences.1-4.

87. Uhunmwangho, R., B. Leesi, and A. Big-Alabo, Application of Genetic Algorithm to Solar Panel Efficiency; A Case Study of PortHarcourt Metropolis. International Journal of Engineering and Technology, 2020. 4: $60-69$.

88. Siddiqui, M.S., B.K. Pant, A.K. Saxena, Shivangi, and S. Chandril. An analysis of Passivated emitter and rear contact (PERC) cell and module. in 2019 IEEE 46th Photovoltaic Specialists Conference (PVSC). 2019.0334-0338.

89. Dullweber, T., M. Stöhr, C. Kruse, F. Haase, M. Rudolph, et al., Evolutionary PERC+ solar cell efficiency projection towards 24\% evaluating shadow-mask-deposited poly-Si fingers below the Ag front contact as next improvement step. Solar Energy Materials and Solar Cells, 2020. 212: 1-8.

90. Yan, W.S., X.Y. Tan, L. Guan, H.P. Zhou, X.B. Yang, et al., Solution of efficiency loss in thinned silicon PERC solar cells. Renewable Energy, 2021. 165: 118-124.

91. Balaji, N., D. Lai, V. Shanmugam, P.K. Basu, A. Khanna, et al., Pathways for efficiency improvements of industrial PERC silicon solar cells. Solar Energy, 2021. 214: 101-109.

92. Yin, E. and Q. Li, Unsteady-state performance comparison of tandem photovoltaic-thermoelectric hybrid system and conventional photovoltaic system. Solar Energy, 2020. 211: 147-157.

93. Farooq, W., A.D. Khan, A.D. Khan, A. Rauf, S.D. Khan, et al., Thin-Film Tandem Organic Solar Cells With Improved Efficiency. IEEE Access, 2020. 8: 74093-74100.

94. Garrison, R. and R. Kleiman, Higher efficiency tandem solar cells through composite-cell current matching. Optics Express, 2019. 27(8): A543-A571.

95. Song, Z., D. Zhao, C. Chen, R.H. Ahangharnejhad, C. Li, et al. Monolithic Two-Terminal All-Perovskite Tandem Solar Cells with Power Conversion Efficiency Exceeding 21\%. in 2019 IEEE 46th Photovoltaic Specialists Conference (PVSC). 2019.0743-0746.

96. Dagar, J., S. Castro-Hermosa, G. Lucarelli, A. Zampetti, F. Cacialli, et al., Low-Temperature Solution-Processed Thin SnO2/Al2O3 Double Electron Transport Layers Toward 20\% Efficient Perovskite Solar Cells. IEEE Journal of Photovoltaics, 2019. 9(5): 1309-1315.

97. Havid Aqoma, I.F.I., Febrian Tri Adhi Wibowo, Narra Vamsi Krishna, Wooseop Lee, Ashis K. Sarker, Du Yeol Ryu, Sung Yeon Jang, High-Efficiency Solution-Processed Two-Terminal Hybrid Tandem Solar Cells Using Spectrally Matched Inorganic and Organic Photoactive Materials. Advanced Energy Materials, 2020. 10(37): 1-10.

98. Zheng, X., A.Y. Alsalloum, Y. Hou, E.H. Sargent, and O.M. Bakr, All-Perovskite Tandem Solar Cells: A Roadmap to Uniting High Efficiency with High Stability. Accounts of Materials Research, 2020. 1(1): 63-76.

99. Pan A., L.H., Zhang L., Experimental Investigation of Dust Particle Deposition Reduction in Solar Cell Covering Glass by SuperHydrophobic Coatings., in Proceedings of the 11th International Symposium on Heating, Ventilation and Air Conditioning (ISHVAC 2019).ISHVAC 2019. , Z.Y. Wang Z., Wang F., Wang P., Shen C., Liu J., Editor. 2020, Springer, Singapore. 827-834

100. Sugiartha, N., I.G.N.A. , I.M.S. , I.B.G.W. , I.N.S. , et al., Preliminary design and test of a water spray solar panel cleaning system. Journal of Physics: Conference Series, 2020: 1-7.

101. Zhang, L.-z., A.-j. Pan, R.-r. Cai, and H. Lu, Indoor experiments of dust deposition reduction on solar cell covering glass by transparent super-hydrophobic coating with different tilt angles. Solar Energy, 2019. 188: $1146-1155$

102. Nyarko, F.K.A., G. Takyi, and E.H. Amalu, Robust crystalline silicon photovoltaic module (c-Si PVM) for the tropical climate: Future facing the technology. Scientific African, 2020. 8: 1-40.

103. Pradhan, A., B. Panda, B. Panda, and A. Khillo, An Improved MPPT Technique for Increasing Efficiency of PV Module. 2020. 633-644.

104. Zhu, Z., K. Mao, and J. Xu, Perovskite tandem solar cells with improved efficiency and stability. Journal of Energy Chemistry, 2021: 219-232.

\section{AUTHORS PROFILE}

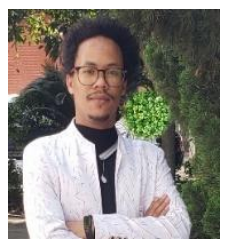

lithium batteries.

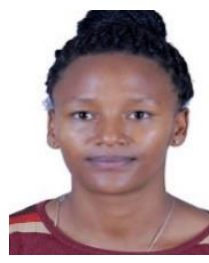

Temesgen Abera Takiso, received his master's degree in Industrial Engineering from Hunan University, China. He has graduated Bachelor of Science Degree in Electromechanical Engineering from Hawassa University, Ethiopia. Currently he is a $\mathrm{PhD}$ degree student in Mechanical Engineering at Hunan University, China. His research interests are Renewable energy like solar energy and Sulphur

Birtukan Tekle Manbecho, received her Master's degree in Industrial Engineering from Hunan University, China. She has get her undergraduate Degree (B.Sc.) in Civil Engineering from Hawassa University, Ethiopia. Currently she is working in the basic Infrastructure of the municipality of Gimbichu city, Ethiopia. Her research interests are construction Material Management and Renewable Energy.

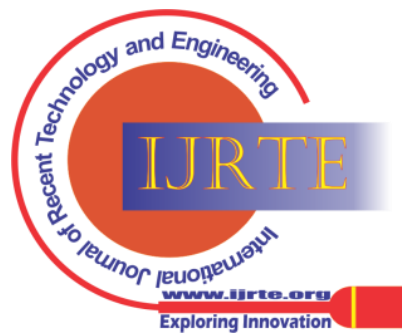

